\title{
THE UNIVERSITY OF THE THIRD AGE AS AN INSTITUTION COUNTERACTING MARGINALIZATION OF OLDER PEOPLE
}

\author{
AlEKSANDRA MARCINKIEWICZ \\ al.marcinkiewicz@gmail.com
}

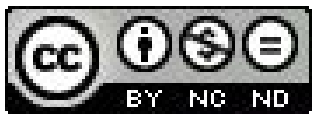

\begin{abstract}
The article presents the role of the University of the Third Age in counteracting the effects of marginalization of the elderly. The history of the University of the Third Age is presented and also different models of this institution are characterized. The paper presents new trends in research conducted by participants of the U3A and shown their relation to marginalization.

Key words: University of the Third Age, social exclusion, marginalization, seniors, Lifelong Learning

The progressive process of aging population mean that resultant issues are a significant aspect of research. The importance of preparing people to grow old meaningfully in the University of the Third Age is called the crown of Lifelong Learning. It is an institution designed for the elderly and its goal is the optimization of their living conditions and creating opportunities for comprehensive development (Czerniawska 2009, p.98).

The origins of the institutions can be found in XIXth Denmark in the idea of The People's University which was created by Nicolai Frederik Severin Grundtvig (Półturzycki 1994, p.19). The first facility of this kind addressed to the elderly, named the University of the Third Age (U3A) was founded in France in 1973 on the initiative of Pierre Vallas professor of international law and the sociology. It should be noted that the emergence of the U3A was preceded by the creation of many international ${ }^{1}$ and local organizations for seniors. It reflects a growing interest in the elderly.

The classic model of the Third Age University assumes that this is a gerontology and university institution. Therefore researchers focus on problems of old age and contribute to the optimization of living conditions of seniors. It should be noted, that the aim is not only to improve the living conditions of people who

The most important organizations for the elderly, which preceded the establishment of the U3A include: International Association of Gerontology (IAG), Fédération Européenne pour les Personnes âgées (EURAG), Centre International de Gérontologie Sociale (CIGS), European Centres for Social Welfare Training of Research (ECSWTR). As a result, representatives of those organizations created in 1980 Fédératiom Internationale des Associations des Personnes Âgées (FIAPA), which was respected by UN and EU (R. Konieczna- Woźniak, 2001, p. 39-40). Another organization for the elderly is the European Federation of Older Students (EFOS), founded in 1990. EFOS Activities include: supporting academic research of the elderly in the U3A, promotion of joint projects of the U3A in Europe and ensure access of the elderly in academic education (20 Years of EFOS 1990-2010, 15.11.2011).
\end{abstract}


are in older age but also help their comprehensive development. The University of the Third Age is a part of Lifelong Learning, so it should promote health education, inspire intellectual activity, physical activity and artistic expression, as well as supporting active attitude in the local environment (Czerniawska 2007, p. 216).

The experiences of various forms of seniors education in the second half of the twentieth century and individual education systems in different countries, as well as different conditions for the social development created the idea, structure and scope of activities in the U3A which over time have changed (Schmidt 2002, p. 132). In addition to the classical model described above, there are also different ones. Jerzy Halicki singled out other models (beyond classic model). The British model was developed by Paul Lasletta and it assumes the self-help character of U3A. Therefore, there are not divisions into students and teachers and the classes are organized by students. The role of the university is to create ways of working with older people, and organizing a network of universities with a panel to oversee their operation (Halicki 2000, p. 42-51).

In the United States an equivalent of the University of the Third Age is the Elderhostel. The concept of Elderhostel assumes education of elderly at a high level with adventure and travel (a few days classes and trip). An important assumption of this idea was to present new opportunities meaningful and productive life in the community (Halicki 2000, p. 42-51).

Olga Czerniawska beyond these intermediate options also distinguishes the model of the Chinese and the internet. The internet model was created in Australia and it enables immigrants to learn the native language. However, the Chinese concept enables learning of professional and cultural skills. Its aim is to care for culture and customs which are important for older Chinese, who after the Cultural Revolution became the only generation that could save the cultural heritage. In addition to foreign languages, computer science, or sign language, the U3A teaches calligraphy, painting, dance, the basis of natural medicine etc. (Czerniawska 2009, p. 99-100).

The creation of intermediate models illustrates the needs and abilities of societies which formed them. New trends investigation in the U3A are visible in the character and themes of research. Integrity was the first trend indicated by $\mathrm{O}$. Czerniawska. One of the activities of this subject was the project implemented at the University of Namur in Belgium in 2004 which relied on the cooperation of elderly people with children to create a proverbs encyclopaedia. The children processed and recorded on a CD compiled by the older generation of proverbs, allowing transfer of proverbs to the information society (Czerniawska 2007, p. 223).

New technologies in science as well as intergenerational and intercultural transmission is another important trend in the work of the U3A. An example of a research project based on the Internet is created in 1995 in the Ulm Centre "European Network in Later Life," which leads through a network of higher education.

Another trend that is reflected at the Universities of the Third Age is a voluntary service, which compares to the British model. In addition to classes and courses in large groups conducted by professionals, small research groups where students share their experience and ideas are created in the U3A. Another form of volunteering helps disabled children, and people in need (Czerniawska 2007, p. 223). 
A new term described in literature is "the fourth generation" which characterizes seniors over the age of eighty. Therefore, there is the idea of the establishment of the University of the Fourth Age, which is to be directed to this group of students. Seniors are divided into young-seniors and old-seniors. The University of Fourth Age should be an online university, enabling education at home, allowing disabled seniors to participate in society (Czerniawska 2007, p.223). With high probability, it will be another area of activity of the University of the Third (Fourth) Age.

New trends in the U3A are not only an expression of new research interests, but also point out problems and needs of older people. Just as new intermediate model U3A, trends show what is especially important for members of the university. These trends arise from the needs of seniors, so they are an attempt to identify ways to satisfy them.

There is no doubt that the specific needs of seniors are the effect of their progressive age. Old age is often referred to as a process which results in a deterioration of the human being. This assumption is consistent with the theory of stratification by age, where age is a major determinant which defines an access to commonly desired goods. The effect is that old people have less access to those goods. As a result, older people have less access to these goods. Seniors lose their social position as a result the cessation of job, reduction of earnings, narrowing of the network of informal contacts (Szweda-Lewandowska 2011, p.169-179). This situation increases the likelihood of marginalization and social exclusion of the elderly.

The concept of marginalization and social exclusion are not clear and could be defined in different ways. Monika Parchomiuk believes that social exclusion is an advanced form of marginalization. This phenomenon could be characterized dynamically as process or statically as a situation. Thus, marginalization means limited access (full or partial) to various systems (social, economic, cultural and political) which help a person in social integration (Parchomiuk 2006, p. 4).

The commission of the European Union recognizes the social exclusion as a process, whose effect is marginalization of people which, due to lack of basic skills and education are not allowed to participate fully in society. Marginalized people have limited access to decision-making centers of power and they feel helplessness and inability to influence the decisions which affect their lives (Golinowska, Broda -Wysocki 2005, p. 47). It is possible to distinguish different kinds of marginalization:

- social of a structural nature - resulting from place of residence, low level of education etc.;

- physical - associated with disability or old age;

- normative - associated with loneliness, addiction or conflict with the law.

Due to the fact that these considerations relate to older people, social exclusion of a structural nature, which is associated with low education, referred to as intellectual exclusion. The physical exclusion as biological and normative as psychophysical.

Analyzing U3A activities which aim at counteracting marginalization it should be taken into account those that directly impact on seniors and those that have consequences on society. These are the reasons to justify why U3A should primarily effect the elderly, in such a way as to enhance their ability to overcome barriers 
and promote their participation in society. However, the impact on society should lead to full acceptance of this group of people by changing the image of an elderly person, as well as drawing attention to their problems.

Beata Ziębińska believed that the role of the University of the Third Age is to counteract the marginalization of seniors by different forms of activities: social, physical and intellectual. B. Ziębińska focused on actions of the U3A targeted at units which should develop the ability to cope with the obstacles which prevent seniors from full participation in society (Ziębińska 2010, p. 259-267). Similar opinions about the role of the U3A are presented by Renata Konieczna-Woźniak who concentrated on the preventative aspect of seniors' education (Konieczna-Woźniak 2007, p. 98-102). This way of thinking results from the definition of marginalization. Social activity is realized by a peer support team. The aim of this group is to maintain relationship with students who do not attend to university because they are ill. Its activity relies on mental and financial support of seniors in a crisis. It can be concluded that participation in the U3A allows development of informal contacts, which is helpful in difficult situations. Seniors' social activity is also expressed by working within self-government of the university. Another way of social activity is volunteering in the local environment often in cooperation with non-profit organizations. These actions result from the specific local environment, therefore it is difficult to identify the specific areas of interaction. Researches show that the University of the Third Age mostly activates seniors by its own actions such as support teams, work in self-government and attending many kinds of courses. However the U3A is also place where it is possible to find new social roles like volunteering (Ziębińska 2010, p. 259-267).

The prophylaxis of gerontology is understood as a broad range of impacts to counter the negative effects of human aging. One of its aspects is the intellectual activity of older people. At the University of the Third Age, this activation takes place through lectures, sections, seminars, science clubs and a variety of courses. The main activities in this area are lectures, mostly on the protection of health and medicine related to diseases of old age. Sections, seminars, and science clubs are improving knowledge, often enriched with their own creativity which is a way of further development of persons in older age. The creative process allows less fragmentary perception of reality. It is closely coupled with the process of learning. The U3A also helps to develop the competencies needed in the information society, such as computer skills, using internet and learning of foreign languages. New competences could be useful in the everyday life of elderly (Ziębińska 2010, p. 274-276).

Another area of consideration in terms of intellectual activity are senior's researches in the U3A. This issue that can be viewed in different ways: first, as scientific research by students themselves; second, as the involvement of students in research conducted by the faculty of gerontology; third, as the dissemination of research results in the area of gerontology in the U3A and beyond. Results show that encouraged by the second form of engagement - students are involved in the research conducted by scientists. Therefore, the academic profile of the U3A should be enriched by a greater number of seniors in research. This is an important field of activity the U3A which testifies to the importance and the scientific authority of the institution (Konieczna-Woźniak 2007, p.113-119). 
Preventive measures recommend physical activity which improves physical and mental health, and also prevents specific diseases of the elderly. Another benefit resulting from physical activity is to change the stereotype of the elderly as infirm, and also maintain an independent lifestyle (Dąbrowska, Skrzek 2002, p. 35-37). R. Konieczna-Woźniak in research analyzed subjective evaluation of physical fitness by seniors. More than half of the respondents $(51.5 \%)$ assessed their health as good, $41.9 \%$ considered it as a medium, only $4.2 \%$ assessed it as bad. Comparing these results with research of Zbigniew Woźniak (He has run a surrey on Poznań residents about their health) the results of physical fitness of students of the U3A are very good. In research of Z. Woźniak respondents assessed their health as very good $(34.4 \%)$, as medium $(25.5 \%)$ as a bad $(40.2 \%)$ (Konieczna-Woźniak 2007, p. 100-102). The above results could have two explanations. First, the discrepancy in the subjective evaluation of physical condition by seniors may be due to the fact that at the U3A attendees are primarily people without disabilities. Another explanation may be that the result of members of U3A are better tha Poznan of residents because of physical activities organized by the University.

Simultaneous activation of the seniors in these areas (social, physic and intellectual) appears to be particularly important, because only in this way can there be a complex effect on the person and maximum increases in abilities to cope with stress situations and other problems. Specific activity should not be recognized separately but in a complementary manner because in that way they can prevent the marginalization resulting from the different areas of operation of the unit.

Referring to the previous mentioned exclusion areas (intellectual, biological, and psychophysical) we can show how the various actions of the Third Age University counteract this negative phenomenon.

\section{Tab. 1. The role of the Third Age University in counteracting the effects of social exclusion.}

\begin{tabular}{|l|l|l|l|}
\hline & \multicolumn{3}{|c|}{ Areas of social exclusion } \\
\cline { 2 - 4 } & Intellectual exclusion & \multicolumn{1}{|c|}{ Biological exclusion } & \multicolumn{1}{|c|}{$\begin{array}{c}\text { Psychophysical } \\
\text { exclusion }\end{array}$} \\
\hline Actions of the U3A & $\begin{array}{l}\text { Intellectual stimulation: } \\
\text { - acquire education; } \\
\text { - Esteem and social } \\
\text { prestige; } \\
\text { - The use of the creative } \\
\text { potential of seniors. }\end{array}$ & $\begin{array}{l}\text { Physical stimulation: } \\
\text { - physical activities; } \\
\text { - trips, } \\
\text { - health education. }\end{array}$ & $\begin{array}{l}\text { Social stimulation: } \\
\text { - volunteering } \\
\text { - building networks of } \\
\text { informal contacts; } \\
\text { - the U3A as a place to } \\
\text { realize individual } \\
\text { needs (theory of } \\
\text { compensation). }\end{array}$ \\
\hline $\begin{array}{l}\text { New trends in research } \\
\text { and actions of the U3A }\end{array}$ & New technology & University of the & $\begin{array}{l}\text { Integrity, } \\
\text { Volunteering }\end{array}$ \\
\hline $\begin{array}{l}\text { Models of working } \\
\text { with seniors }\end{array}$ & French model & American model & British model \\
\hline
\end{tabular}

Source: Prepared by author. 
The social exclusion of a structural nature is associated with for example place of residence or lack of education. While the U3A can have no influence on first variable, education is one area where the university role is significant. The University of the Third Age first of all is a place of intellectual development. Its allows study for those people who did not have the opportunity for education at earlier stages in life. This institution by organization of lessons equips seniors with skills which are necessary in an information based society and facilitates the creative potential of students. Moreover, the fact of attending an academic institution and intellectual development are a reason for respect and social prestige. Confirmation of actions against exclusion is the aim of the intellectual development of new technologies at the university. All models of the U3A include all forms of activities (intellectual, social and physical) but it should be noted that various models place greater emphasis on specific activities, which somehow result from the model. The French model of the U3A in its activities emphasizes the academic aspect of the institution, therefore it should be located in the area of intellectual marginalization. The project which is a response to the marginalization of biological (resulting from a disability or old age) is physical activity of the elderly. These activities are designed to keep seniors in the best possible physical condition, which leads to deferment of disabilities. Interest the U3A in "the fourth age" reflects its willingness to support those people who are disabled and do not have the opportunity to attend at a university. Therefore, disability will not cause social exclusion. The American model of working with seniors, which is characterized by activation of travel and adventure indirectly also emphasizes the physical aspect of aging. This model draws attention to maintaining the best possible condition by the participants and promoting a healthy lifestyle.

The psychophysical exclusion is associated with loneliness which is often felt by older people. The activity of the university in this aspect includes the social activation. Engagement in volunteering, working for the university or environment allowing improvement of the network of informal contacts - new relationships. Moreover, according to the theory of compensation, the university is a place where seniors have an opportunity to meet their individual needs. New trends in the work of the U3A (Integrity and volunteering) confirm activity against marginalization which results from loneliness. It should be noted that volunteering, self-help and self-education are characteristic of the British model.

Undeniably the University of the Third Age significantly affects the quality of life of its students. The U3A activates them all intellectually, socially and physically affecting their ability to cope in difficult situations, thus minimizing the danger of social exclusion. Nevertheless, if the university wants to better counteract marginalization it should effectively impact on society by changing the image of an elderly person. This effect can be achieved by the organization of conferences, publication of scientific and popular work, volunteering, or working with the local community. Please also note that most people who attend to the U3A are of sound physique and educated, so are the intellectual elite of the older generation. Therefore, activities should focus on ways to reach out to the rest of Polish seniors, because only in this way you can talk about really counteracting 
marginalization among the elderly. One solution is the creation of the Third Age Universities in small towns and villages, maintaining high standards of education.

An important aspect in the activities of the U3A should be cooperation between the generations. It is not only about action resulting from the implementation of projects for seniors (although it is very important) but natural cooperation of generations which should be implemented at the University of the Third Age. This understanding of the idea of intergenerational dialogue, not an incidental event but as constant element of the U3A work, making that intergeneration, cooperation will be real. It will change the image of older and young people and not allow a group of closed seniors on their own but enable them greater development.

\section{BIBLIOGRAPHY}

Czerniawska O. (2009), Uniwersytet Trzeciego Wieku, 30 lata dziatania. Przemiany, dylematy i oczekiwania w epoce ponowoczesnej, "Chowanna” 2.

Czerniawska O. (2007), Szkice z andragogiki i gerontologii, Wydawnictwo Wyższej Szkoły Humanistyczno-Ekonomicznej, Łódź.

Dąbrowska G., Skrzek A. (2002), Kultura fizyczna ludzi starych, [in:] Wnuk W. (Ed.), Ludzie starzy w trzecim tysiacleciu. Szanse. Nadzieje. Potrzeby, Alta 2, Wrocław.

Golinowska S., Broda-Wysocki P. (2005), Kategoria ubóstwa i wykluczenia spotecznego. Przeglad ujęć, [in:] Golinowska S., Tarkowska E., Topińska I. (eds.), Ubóstwo i wykluczenie spoteczne. Badania. Metody. Wyniki, Instytut Pracy i Praw Socjalnych, Warszawa.

Golinowska S., Tarkowska E, Topińska I (eds.) (2005), Ubóstwo i wykluczenie społeczne. Badania. Metody. Wyniki, Instytut Pracy i Praw Socjalnych, Warszawa.

Halicki J. (2000), Edukacja seniorów w aspekcie teorii kompetencji. Studium historyczno-porównawcze, Trans Humana, Białystok.

Kowalewski J. (ed.) (2011), Przestrzenne zróżnicowanie starzenia się ludności Polskiej. Przyczyny, etapy, następstwa, Wydawnictwo Uniwersytetu Łódzkiego, Łódź.

Parchomiuk M. (2006), Niepełnosprawni- społecznie wykluczeni?, „Niepełnosprawność i Rehabilitacja” 4. Półturzycki J. (1994), Uniwersytet powszechny, ,Edukacja Dorosłych" 3.

Schmidt L. (2002), Uniwersytet Trzeciego Wieku w Polsce. Jedność w różnorodności (próba diagnozy), [in:] Wnuk W. (ed.), Ludzie starsi w trzecim tysiacleciu: szanse, nadzieje, potrzeby, Alta 2, Wrocław.

Szweda- Lewandowska Z. (2011), Zapotrzebowanie na instytucjonalne formy pomocy osobom starszym $w$ perspektywie dwudziestu pięciu lat w świetle aktualnych determinant w mikro- $i$ makroskali [in:] Kowalewski J. (ed.), Przestrzenne zróżnicowanie starzenia się ludności Polskiej. Przyczyny, etapy, następstwa, Wydawnictwo Uniwersytetu Łódzkiego, Łódź.

Wnuk W. (ed.) (2002), Ludzie starsi w trzecim tysiacleciu: szanse, nadzieje, potrzeby, Alta 2, Wrocław.

\section{NETOGRAPHY}

20 Years of EFOS 1990-2010, http:/ / www.efos-europa.eu/history/, retrieved: 15.11.2011. 